\title{
Outdoor grazing of dairy cows on pasture versus indoor feeding on total mixed ration: Effects on gross composition and mineral content of milk during lactation ${ }^{1}$
}

\author{
Arunima Gulati, ${ }^{\star} \dagger$ Norann Galvin, $\ddagger$ Eva Lewis, $\ddagger$ Deirdre Hennessy, $\ddagger$ Michael O'Donovan, $\ddagger$ \\ Jennifer J. McManus, $\dagger$ Mark A. Fenelon, ${ }^{*}$ and Timothy P. Guinee ${ }^{* 2}$ \\ ${ }^{*}$ Teagasc Food Research Centre Moorepark, Fermoy, Co. Cork, Ireland \\ †Department of Chemistry, Maynooth University, Maynooth, Co. Kildare, Ireland \\ ¥Teagasc, Animal \& Grassland Research and Innovation Centre, Moorepark, Fermoy, Co. Cork, Ireland
}

\begin{abstract}
The influence of feeding system and lactation period on the gross composition, macroelements $(\mathrm{Ca}, \mathrm{P}, \mathrm{Mg}$, and $\mathrm{Na}$ ), and trace elements $(\mathrm{Zn}, \mathrm{Fe}, \mathrm{Cu}, \mathrm{Mo}, \mathrm{Mn}$, Se, and Co) of bovine milk was investigated. The feeding systems included outdoor grazing on perennial ryegrass pasture (GRO), outdoor grazing on perennial ryegrass and white clover pasture (GRC), and indoors offered total mixed ration (TMR). Sixty spring-calving Holstein Friesian dairy cows were assigned to 3 herds, each consisting of 20 cows, and balanced with respect to parity, calving date, and pre-experimental milk yield and milk solids yield. The herds were allocated to 1 of the 3 feeding systems from February to November. Milk samples were collected on 10 occasions over the period June 17 to November 26, at 2 or 3 weekly intervals, when cows were on average 119 to $281 \mathrm{~d}$ in lactation (DIL). The total lactation period was arbitrarily subdivided into 2 lactation periods based on DIL, namely mid lactation, June 17 to September 9 when cows were 119 to 203 DIL; and late lactation, September 22 to November 26 when cows were 216 to 281 DIL. With the exception of $\mathrm{Mg}, \mathrm{Na}, \mathrm{Fe}, \mathrm{Mo}$, and $\mathrm{Co}$, all other variables were affected by feeding system. The GRO milk had the highest mean concentrations of total solids, total protein, casein, Ca, and P. The TMR milk had the highest concentrations of lactose, $\mathrm{Cu}$, and $\mathrm{Se}$, and lowest level of total protein. The GRC milk had levels of lactose, $\mathrm{Zn}$, and $\mathrm{Cu}$ similar to those of GRO milk, and concentrations of TS, Ca, and P similar to those of TMR milk. Lactation period affected all variables, apart from the concentrations of $\mathrm{Fe}, \mathrm{Cu}, \mathrm{Mn}$, and Se.
\end{abstract}

\footnotetext{
Received June 15, 2017.

Accepted August 15, 2017.

${ }^{1}$ Presented as part of the Teagasc-Moorepark/University College Cork Cheese Symposium at the ADSA Annual Meeting, Pittsburgh, Pennsylvania, June 2017.

${ }^{2}$ Corresponding author: tim.guinee@teagasc.ie
}

On average, the proportion (\%) of total Ca, P, Zn, Mn, or Se that sedimented with the casein on high-speed ultracentrifugation at $100,000 \times g$ was $\geq 60 \%$, whereas that of $\mathrm{Na}, \mathrm{Mg}$, or Mo was $\leq 45 \%$ total. The results demonstrate how the gross composition and elemental composition of milk can be affected by different feeding systems.

Key words: pasture, total mixed ration, milk, element

\section{INTRODUCTION}

The composition of bovine milk is influenced by various factors including stage of lactation, nutrition, health status, lactation number, and proportions of cows in a herd calving at different times of the year (O'Brien et al., 1999a,b; O'Callaghan et al., 2016b). The most widely used feeding methods for dairy cows globally include outdoor grazing on pasture, usually with a low quantity of concentrate supplementation offered only at the extremes of the pasture-growing season, or indoors offered TMR composed mainly of silage, grain, and added vitamins and minerals. Pasture-based feeding is common in temperate regions where pasture growth is abundant, including Ireland, New Zealand, and parts of Australia, whereas TMR is used more extensively in the United States, parts of Europe, and the southern hemisphere (O'Callaghan et al., 2017). Pasture composition can vary with region, but generally includes perennial ryegrass (Lolium perenne L.) with other species such as clover (Trifolium repens L.), meadow grass (Poa trivialis L.), cocks's foot (Dactylis glomerata L.), and fescue (Festuca arundinacea L.; O'Mara, 2008). The composition of TMR can vary according to the type and ratio of different feed materials included in the formulation.

Advantages of pasture-based feeding include its cost competiveness, its lower contribution to enteric methane emissions (O'Neill et al., 2011), and provision of a "more natural" environment for animal welfare (Verkerk, 2003). Additional advantages of pasture in- 
corporating clover include atmospheric $\mathrm{N}$ fixation and reduction in nitrous oxide emissions (Ledgard et al., 2009). Advantages of TMR include a more consistent feed composition and quality, better regulation of DMI, and higher milk yield (Kolver and Muller, 1998; McAuliffe et al., 2016).

Several studies have compared the effects of pasture and TMR feeding systems on yield of milk and gross composition. Milk produced using TMR-based feeding has lower concentrations of TS, fat, total protein, true protein, and casein compared with milk from pasturefed cows (O'Callaghan et al., 2016b). Nevertheless, TMR feeding results in higher milk yield, and despite the lower concentrations of TS, a higher yield of milk fat and protein (Kolver and Muller, 1998; McAuliffe et al., 2016). Despite the widespread use of pasture and TMR feeding systems, there is a paucity of published information on the comparative effects of these feeding systems on milk characteristics other than gross composition, such as the profile of proteins and minerals. Minerals such as $\mathrm{Ca}$ and $\mathrm{P}$ are important modulators of protein-protein interactions, casein micelle structure, and the susceptibility of the protein to aggregation during dairy processing (Holt and Jenness, 1984). Consequently, Ca and $\mathrm{P}$ have a major influence on processing characteristics, such as rennet coagulation, heat stability, and ethanol stability (Tsioulpas et al., 2007; Sandra et al., 2012; Horne, 2016). Apart from their effects on protein aggregation (Sievanen et al., 2008; Sandra et al., 2012), variation in mineral content can also alter the nutritional value of milk and milk products (Cashman, 2011a). The role of trace elements in human nutrition has been extensively reviewed (Cashman, 2011b; Gaucheron, 2013); they contribute biological and physiological functions such as the role of Fe in hemoglobin production, $\mathrm{Cu}$ and Se in enzyme functioning, Co as a constituent of vitamin $\mathrm{B}_{12}$, and $\mathrm{Se}$ as a component of glutathione peroxidase, an antioxidant. Further, little is known how trace elements partition between the casein and serum phases of milk, even though this is likely to influence their bioavailability (Cashman, 2011b). Protein and minerals (elements) in first stage (0-6 mo) infant milk formula (IMF) and follow-on formula are provided by the skim milk powder and whey ingredients used in formulation. The total concentration of elements in the latter ingredients determines the level of element fortification required to meet the target label claim for the IMF and follow-on formula (European Commission, 2006; McSweeney et al., 2013; McCarthy et al., 2016). Hence, any changes in the concentrations of protein and elements owing to the feeding system of the dairy cow and stage of lactation could necessitate reformulation of the IMF and affect in-process thermal stability.
The current study was undertaken as part of an overall project collaboration, "Profiling milk from Grass," between Teagasc Food Research Centre Moorepark and Teagasc Animal \& Grassland Research and Innovation Centre Moorepark to address knowledge gaps on the comparative effects of pasture and TMR feeding systems. Recent studies have described the influence of these feeding systems on milk yield (McAuliffe et al., 2016), milk fat composition (O'Callaghan et al., 2016b), and butter quality (O'Callaghan et al., 2016a). The current study investigated the effect of the following feeding systems on the gross composition and concentrations of macroelements and trace elements in milk over the period June to November 2015: outdoor grazing on perennial ryegrass pasture (GRO), outdoor grazing on perennial ryegrass and white clover pasture (GRC), and indoors offered TMR.

\section{MATERIALS AND METHODS}

\section{Details of Herd and Feeding Systems}

Sixty spring-calving dairy cows were allocated to 1 of the 3 groups at the Teagasc Animal and Grassland Research and Innovation Centre, Moorepark, Fermoy, Co. Cork, Ireland, in 2015. Each treatment group consisted of 20 cows and the groups were balanced with respect to breed (48 Holstein Friesian +12 Holstein Friesian $\times$ Jersey), lactation number (12 primiparous + 48 multiparous), calving date (mean calving date February 19, 2015) and pre-experimental milk yield and milk solids yield, as described by McAuliffe et al. (2016). The average Economic Breeding Index value (www.icbf.com) of the 3 herds was $€ 185$ (SD $= \pm € 43$ ). The feeding systems, imposed from mid February [1 d in lactation (DIL)] to November (300 DIL), were outdoor grazing on perennial ryegrass (Lolium perenne L.) pasture (GRO), outdoor grazing on perennial ryegrass and white clover (Trifolium repens L.) pasture (GRC), or indoors offered TMR (TMR).

The GRO and GRC swards were fertilized at $250 \mathrm{~kg}$ of N/ha per yr. Nitrogen was applied to GRO and GRC swards treatments as urea $(46 \% \mathrm{~N})$ until the end of April and as calcium ammonium nitrate $(27 \%$ N) from early May to mid September. The grazing treatments were stocked at 2.75 livestock units/ha in a fully closed farm system. Both grazing groups were rotationally grazed, achieving 8.3 grazing rotations in the season. Cows remained in their treatment groups for the entire lactation. Grass was allocated to the grazing groups each day to achieve a postgrazing sward height of 4 $\mathrm{cm}$. Pasture allocation for the grazing treatments was measured using pre-grazing herbage mass $(>4 \mathrm{~cm})$ and area $\left(\mathrm{m}^{2}\right)$. Average sward clover content across the 
year was $23.8 \%$ of herbage DM. The target pre-grazing herbage mass was between 1300 and $1600 \mathrm{~kg}$ of DM/ ha above $4 \mathrm{~cm}$. The daily DMI for cows on the GRO and GRC swards was $18 \mathrm{~kg} /$ cow per d. Grazing cows received a mineral supplement in the form of a liquid mineral preparation injected into the water supply (Terra Liquid Minerals, Moone Lodge, Moone, Athy, Co. Kildare, Ireland), giving a mean intake (mg/cow per d) of $\mathrm{Na}, \mathrm{Mg}, \mathrm{Zn}, \mathrm{Cu}$, Se, and Co of 5.0, 1.2, 219, 106, 3.8, and 3.0, respectively. The GRO and GRC diets were supplemented with concentrates at a level of $2 \mathrm{~kg}$ per cow in November for a period of $25 \mathrm{~d}$, which included the last 2 sampling occasions when the cows were 257 and 281 DIL, respectively. During this period, the DMI decreased to $17 \mathrm{~kg} /$ cow per d.

The TMR diet consisted of grass silage, maize silage, and concentrates, including beet pulp, soybean meal, maize distillers grains, rolled barley, rapeseed meal, Megalac, Acid Buf, and mineral balancer (O'Callaghan et al., 2016b). The DMI of TMR-fed cows was $7.15 \mathrm{~kg}$ of grass silage, $7.15 \mathrm{~kg}$ of maize silage, and $8.3 \mathrm{~kg}$ of concentrate. The concentrate portion of the TMR feed was supplemented with a commercial mineral balancer, Dairy Hi-Phos (McDonnell Bros. Agricultural Suppliers Ltd., Fermoy, Co. Cork, Ireland) to give added Ca, Na, $\mathrm{P}, \mathrm{Zn}, \mathrm{Cu}, \mathrm{Mn}, \mathrm{I}, \mathrm{Co}$, and Se of 3,340, 2,000, 1,200, 140, $100,70,10,2$, and $0.8 \mathrm{mg} / \mathrm{kg}$, respectively.

\section{Milk Sampling}

Milk samples were collected from each of the treatment herds on 10 occasions, at 2 or 3 weekly intervals, from June 17 (119 DIL) to November 26 (281 DIL). Evening (pm) and morning (am) milk from each herd was collected separately in designated refrigerated bulk tanks $(5,000 \mathrm{~L})$. The evening milk was held at $4^{\circ} \mathrm{C}$ overnight and the morning milk was cooled in-line to $\sim 15^{\circ} \mathrm{C}$ en route to the bulk tank, as described by O'Callaghan et al. (2016b). Following completion of morning milking, the collected am and pm milks were agitated intermittently for $\sim 30 \mathrm{~min}$ before sampling. A representative 2-L sample of each milk was then withdrawn through the sampling port into clean glass bottles and taken immediately to the laboratory.

\section{Preparation of Skim Milk}

The raw milk was skimmed to reduce fat content to $\leq 0.1 \%$ (wt/wt) fat to avoid contamination of the milk serum, which was subsequently prepared as discussed below. Skimming was performed using a disc bowl centrifuge (FT15 Disc Bowl Centrifuge, Armfield Limited, Ringwood, UK); the skim milk was preserved using sodium azide $(0.2 \%$, wt/wt; Sigma-Aldrich, St.
Louis, MO) and held at $4^{\circ} \mathrm{C}$ for $<12 \mathrm{~h}$ until required for preparation of milk serum, as described below. Representative sub-samples for mineral analysis (20 $\mathrm{mL}$ ) were stored at $-20^{\circ} \mathrm{C}$ and thawed at $4^{\circ} \mathrm{C}$ overnight before analysis.

\section{Preparation of Skim Milk Serum}

Triplicate samples $(16 \mathrm{~mL})$ of each skim milk were ultracentrifuged at $100,000 \times g$ at $25^{\circ} \mathrm{C}$ for $1 \mathrm{~h}$ in a Sorvall Discovery 90SE ultracentrifuge fitted with a fixedangle Sorvall Titanium-1270 rotor (Kendro Laboratory Products, Asheville, NC). The supernatant (serum) was filtered through glass wool to obtain fat-free serum, and stored at $-20^{\circ} \mathrm{C}$ until analyzed for minerals.

\section{Gross Composition of Milk}

Milk was analyzed in duplicate for total nitrogen (TN) using the Kjeldahl method (IDF, 2001). Total solids, lactose, and fat were analyzed in triplicate using the FOSS MilkoScan FT+ analyzer (N. Foss Electric A/S, Hillerød, Denmark). Casein content was determined indirectly by measuring noncasein nitrogen (NCN; ISO, 2004). Skim milk was acidified to $\mathrm{pH} 4.6$ using sodium acetate-acetic acid buffer, and filtered through Whatman No. 42 filter paper (Whatman 1442-50l, GE Healthcare Life Sciences, Little Chalfont, UK). The $\mathrm{N}$ content of the filtrate was measured using the Kjeldahl method and casein was calculated using the formula: casein $(\%, \mathrm{wt} / \mathrm{wt})=(\mathrm{TN}-\mathrm{NCN}) \times 6.38$, where 6.38 is the N-to-protein conversion factor.

\section{Element Analysis}

The following chemicals were used: nitric acid ( $>69.0 \%$ TraceSELECT, for trace analysis) and hydrochloric acid ( $>37 \%$, TraceSELECT, for trace analysis; Fluka Analytical, Sigma-Aldrich Ireland Ltd., Arklow, Co. Wicklow, Ireland); hydrogen peroxide (30\%, AnalaR NORMAPUR for trace analysis; VWR International $\mathrm{BDH}$ chemicals VWR, Dublin, Ireland); calibration multi standard (Inorganic Ventures, Christiansburg, VA); and standard reference material 1849a (LGC Standards, London, UK).

The concentrations of $\mathrm{Na}, \mathrm{Ca}, \mathrm{Mg}, \mathrm{P}, \mathrm{Zn}, \mathrm{Fe}, \mathrm{Cu}$, $\mathrm{Mn}, \mathrm{Co}, \mathrm{Mo}$, and Se in skim milk and skim milk serum were analyzed using inductively coupled plasma MS (Agilent ICPMS 7700x, with ASX-500 series autosampler and MassHunter software A.01.02 Patch 4), using the following modification of the method described by Reid et al. (2015). Skim milk (1 g), serum (2 g), and standard reference material 1849a $(0.5 \mathrm{~g})$ were each digested with $5 \mathrm{~mL}$ of concentrated $\mathrm{HNO}_{3}, 0.5 \mathrm{~mL}$ of concentrated $\mathrm{HCl}$, and $2 \mathrm{~mL}$ of $\mathrm{H}_{2} \mathrm{O}_{2}$. The acid-digested 
samples were diluted to $50 \mathrm{~g}$ with Milli-Q water and analyzed for $\mathrm{Cu}, \mathrm{Co}, \mathrm{Fe}, \mathrm{Se}, \mathrm{Mn}$, and Mo using inductively coupled plasma MS. A portion of the diluted digest was further diluted 1:4 with $3.6 \%$ (vol/vol) nitric acid before analysis of $\mathrm{Ca}, \mathrm{P}, \mathrm{Mg}, \mathrm{Na}$, and $\mathrm{Zn}$. A Multi-Element Standard solution (Inorganic Ventures) with different concentrations of each element, diluted in $3.6 \%$ ( vol/vol) $\mathrm{HNO}_{3}$ to give a range of concentrations $(0,0.1,0.5,1,2,5$, or $10 \mathrm{ppb})$ was used for instrument calibration. The wavelength of plasma emission used was 315.6, 213.6, 279.1, 588.9, 214.4, 259.9, 324.8, 257.6, 228.6, and $204 \mathrm{~nm}$ for $\mathrm{Ca}, \mathrm{P}, \mathrm{Mg}, \mathrm{Na}, \mathrm{Zn}, \mathrm{Fe}, \mathrm{Cu}$, $\mathrm{Mn}, \mathrm{Co}$, and Se, respectively.

The proportion of each element that was sedimentable on ultracentrifugation was then calculated as the difference between the concentration of the element in skim milk and that of the serum, expressed as a proportion (\%) of that in skim milk.

\section{Statistical Analysis}

The data were classified by 3 feeding systems (GRO, GRC, and TMR) and 2 lactation periods based on DIL, namely mid lactation from June 17 to September 9 when cows were 119-203 DIL, and late lactation from September 22 to November 26 when cows were 216-281 DIL. The data were analyzed by ANOVA as a factorial design looking at the main effects of lactation period, feeding system, and their interaction using the general linear model (GLM) procedure of SAS 9.3 (SAS Institute Inc., Cary, NC). Tukey's multiple-comparison test was used for paired comparison of means and the level of significance was determined at $P<0.05$. Mid-lactation milk, denoted ML milk, refers to the composite of the milk samples collected from the herds on the GRO, GRC, and TMR feeding systems in mid lactation; the composite of the late-lactation milk samples was similarly denoted as LL milk. Milk from GRO, GRC, or TMR feeding systems in mid lactation is coded as GRO-ML, GRC-ML, and TMR-ML, respectively; milk samples from GRO, GRC, or TMR feeding systems in late lactation (GRO-LL, GRC-LL, TMR-LL) were similarly denoted.

The R-3.2.2 software (R Core Team, 2014) was used to compute a Pearson correlation between the different compositional variables, where significance was determined at $P<0.05, P<0.01$, and $P<0.001$, according to Student's $t$-test.

\section{RESULTS AND DISCUSSION}

\section{Gross Composition: Fat, Protein, and Lactose}

The composition of milk from the different feeding systems are presented in Table 1 . The concentrations of fat, protein, casein, and lactose were affected by feeding system, lactation period, and the interaction of feeding system and lactation period.

Most notably, the GRO milk had highest mean concentrations of TS, total protein, and casein, and TMR milk had the highest concentration of lactose $(P$ $<0.01)$. Conversely, TMR milk had lowest mean level of total protein $(P<0.01)$. The mean protein content of the GRO milk $(3.98 \%)$ was similar to that reported by O'Callaghan et al. (2016b) but markedly higher than that reported by Mehra et al. (1999) for bulk silo milk collected from pasture-fed spring-calved herds $(3.20-3.75 \%)$ over a similar part of the season (June 2 -November 19). The relatively high protein content of the GRO milk most likely reflects the improvements in husbandry practices, nutritional intake, lactation number, and genetic merit in the last 2 decades. The higher casein content of the GRO milk is expected to favor enhanced rennet gelation and higher cheese yield (Guinee et al., 2006). The mean fat content of the GRO milk was higher than that of the GRC milk but not differerent from that of the TMR milk $(P>$ $0.05)$.

Milk composition changed significantly with the lactation period. The LL milk had higher mean concentrations of TS, fat, total protein, and casein than ML milk; conversely, the lactose content of ML milk was higher than that of LL milk. The increase in levels of total protein and casein over the experimental period for milk from all feeding systems is typical of that reported for the effect of stage of lactation in spring-calved herds (Mehra et al., 1999).

\section{Component Yields}

The yields of milk, TS, fat, protein, casein, and lactose are shown in Table 1 . Yields were significantly affected by feeding system, lactation period, and their interaction.

The TMR feeding gave a significantly higher yield of milk and all milk components (TS, fat, protein, casein, and lactose) than the GRO or GRC feeding systems. The higher milk yield with TMR, therefore, more than compensated for its relatively lower concentrations of TS, protein, casein, and fat. The difference between the feeding systems with respect to milk yield and component yields is consistent with the findings of previous studies (Kolver and Muller, 1998; McAuliffe et al., 2016). The higher yield of milk from TMR feeding is attributed to a higher DMI (Kolver and Muller, 1998).

The yield of milk and milk solids (lactose, fat, total protein, and casein) were significantly higher in ML milk than in LL milk. 
Table 1. Seasonal variation in the compositional characteristics of milk from cows on different feeding systems ${ }^{1,2,3}$

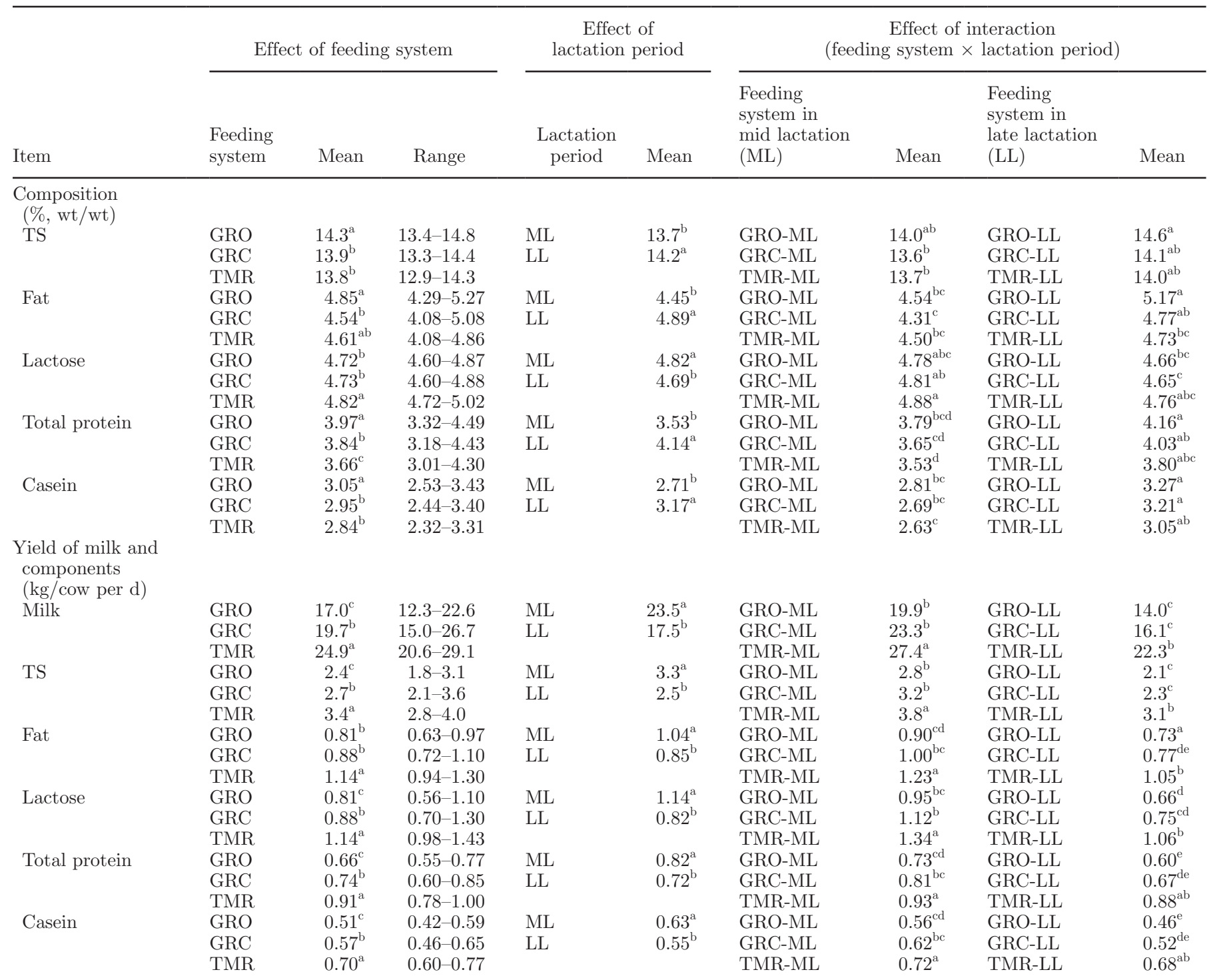

${ }^{\mathrm{a}-\mathrm{e}}$ Values within a column relating to effect of feeding system (GRO, GRC, or TMR) and not sharing a common superscripted letter (a-c) differ significantly $(P<0.05)$. Values within a column relating to effect of lactation period (ML or LL) and not sharing a common superscripted letter $(\mathrm{a}, \mathrm{b})$ differ significantly $(P<0.05)$. Values for mid-lactation and late-lactation milk samples (GRO-ML, GRC-ML, TMR-ML, GRO-LL, GRCLL, or TMR-LL) relating to effect of interaction and not sharing a common superscripted letter (a-e) differ significantly $(P<0.05)$.

${ }^{1}$ Feeding system: GRO = outdoor grazing on perennial ryegrass pasture; GRC = outdoor grazing on perennial ryegrass and white clover pasture; $\mathrm{TMR}=$ indoors offered TMR.

${ }^{2}$ Lactation period: ML and LL refer to mid lactation (June 17-September 9) and late lactation (September 22-November), when cows were 119-203 and 217-281 d in lactation, respectively.

${ }^{3}$ Interaction of feeding system and lactation period: ML milk samples from GRO, GRC, or TMR feeding systems are denoted as GRO-ML, GRCML, or TMR-ML, respectively, and the corresponding LL milk samples as GRO-LL, GRC-LL, or TMR-LL, respectively.

\section{Macroelements in Skim Milk}

Changes over the experimental period in the concentration of macroelements and the proportions of each that sedimented with the casein on high-speed ultracentrifugation are shown in Figure 1. The range and mean for total concentration of macroelements together with the proportion of individual elements that sedimented on high-speed ultracentrifugation are also shown in Table 2.

Calcium. The range of $\mathrm{Ca}$ concentration for all milk samples collected over the experimental period was similar in magnitude to that (113-147 mg/100 g) reported by Auldist et al. (2004), but relatively high compared with the values reported in other studies for milk from spring-calved herds [e.g., $\sim 111-133 \mathrm{mg} / 100$ 
A
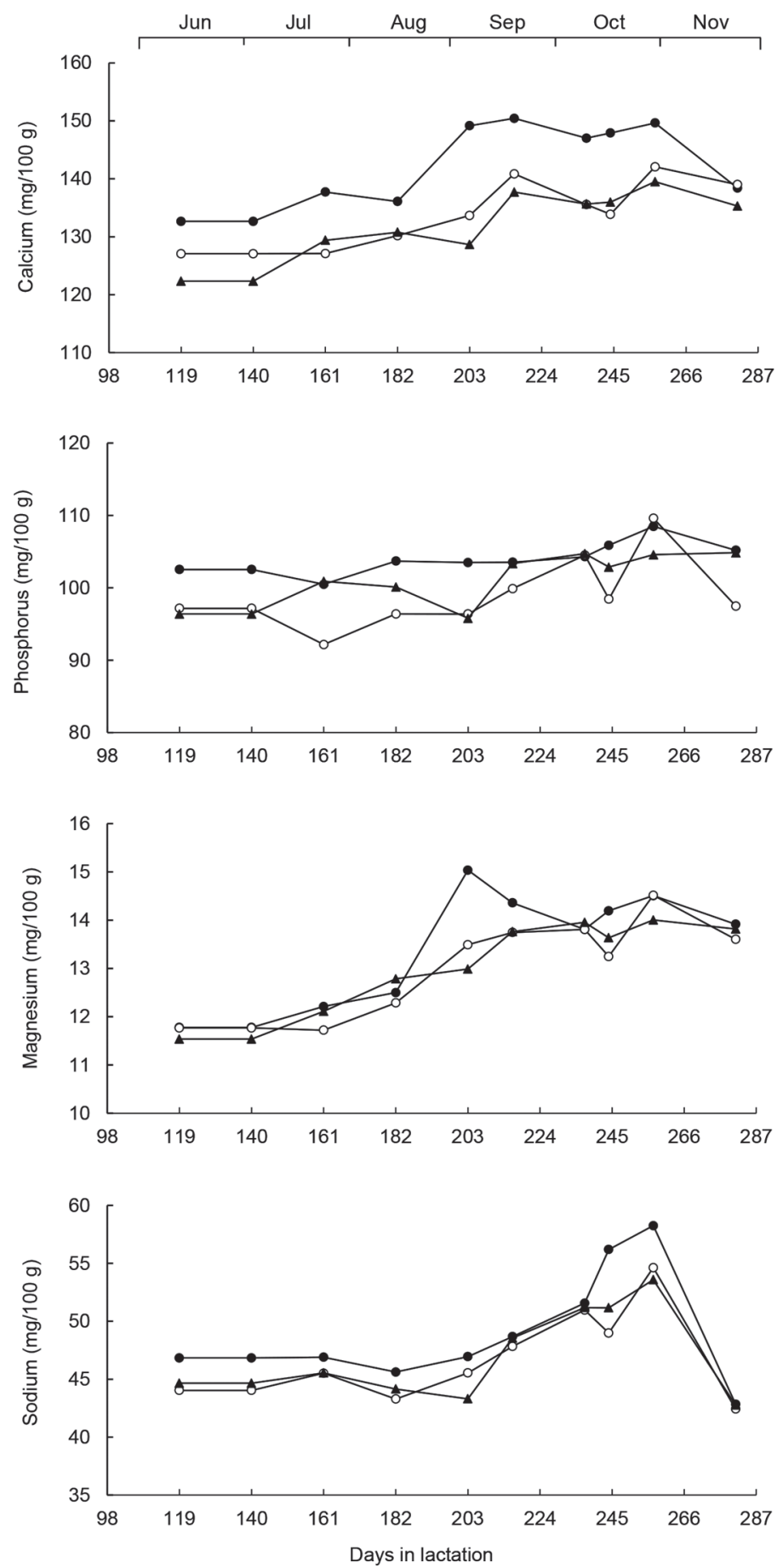

B
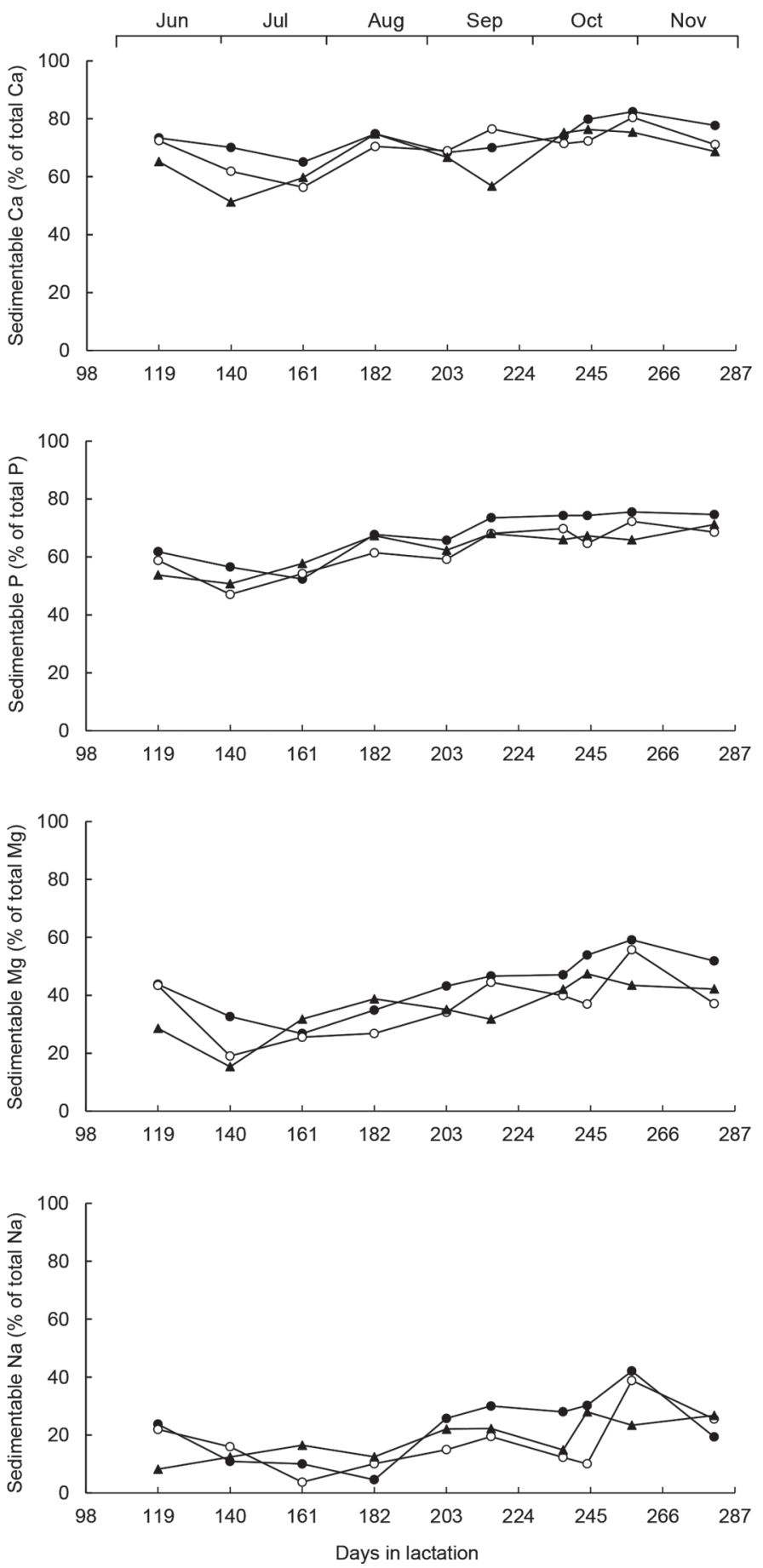

Figure 1. Seasonal variation in the concentration of macroelements in skim milk from spring-calved herds fed using 3 different feeding systems: total concentration (A) and the proportion of each element that sedimented with the casein on ultracentrifugation at $100,000 \times g$ for $1 \mathrm{~h}$ at $25^{\circ} \mathrm{C}(\mathrm{B})$. The different feeding systems were outdoor grazing perennial ryegrass pasture (GRO; $\bullet$ ), outdoor grazing perennial ryegrass and white clover pasture (GRC; O), or indoors offered TMR (TMR; $\mathbf{\Delta})$. Milk from each of the feeding systems was analyzed over the period June 17 to November 26, 2015. 
Table 2. Seasonal variation in the concentration of macroelements, and the proportions that sediment with casein on ultracentrifugation, in skim milk from cows on different feeding systems ${ }^{1,2,3}$

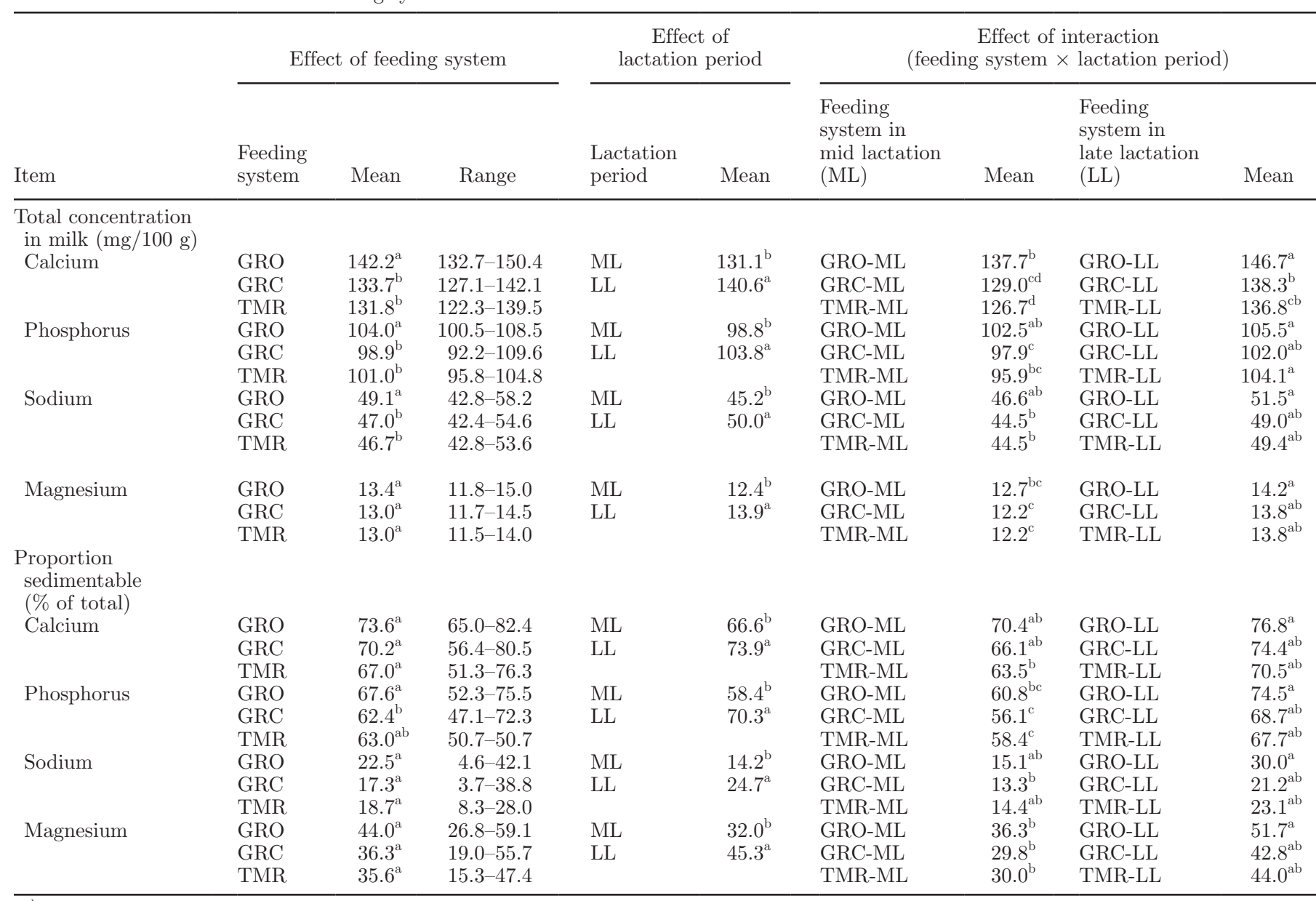

${ }^{\mathrm{a}-\mathrm{d}}$ Values within a column relating to effect of feeding system (GRO, GRC, or TMR) and not sharing a common superscripted letter (a,b) differ significantly $(P<0.05)$. Values within a column relating to effect of lactation period (ML or LL) and not sharing a common superscripted letter $(\mathrm{a}, \mathrm{b})$ differ significantly $(P<0.05)$. Values for mid-lactation and late-lactation milk samples (GRO-ML, GRC-ML, TMR-ML, GRO-LL, GRCLL, or TMR-LL) relating to effect of interaction and not sharing a common superscripted letter (a-d) differ significantly $(P<0.05)$.

${ }^{1}$ Feeding system: GRO = outdoor grazing on perennial ryegrass pasture; GRC = outdoor grazing on perennial ryegrass and white clover pasture; $\mathrm{TMR}=$ indoors offered TMR.

${ }^{2}$ Lactation period: ML and LL refer to mid lactation (June 17-September 9) and late lactation (September 22-November), when cows were 119-203 and 217-281 d in lactation, respectively.

${ }^{3}$ Interaction of feeding system and lactation period: ML milk samples from GRO, GRC, or TMR feeding systems are denoted as GRO-ML, GRCML, or TMR-ML, respectively, and the corresponding LL milk samples as GRO-LL, GRC-LL, or TMR-LL, respectively.

$\mathrm{g}$ (Keogh et al., 1982) and 111-138 mg/100 g (O'Brien et al., 1999b)].

Calcium content was significantly affected by feeding system, lactation period, and their interaction (Table 2; Figure 1). The mean Ca content of GRO milk was higher $(P<0.05)$ than that of GRC or TMR milk. The high $\mathrm{Ca}$ content of the GRO milk reflects its higher casein concentration, as evidenced by the similar mean values for Ca-to-protein ratio for GRO, GRC, and TMR milk (33.6-34.4 mg/g of protein; data not shown). Most of the $\mathrm{Ca}$ in milk exists in association with $\mathrm{P}$ as an insoluble calcium phosphate hydroxyapatite attached to the caseins where it contributes to the structural integrity of the casein micelle (de Kruif et al., 2012). The association of calcium phosphate with casein ensures that calcium phosphate, which otherwise would be insoluble, remains dispersed or "soluble" and thereby, provides for the nutrition of the neonate for which calcium phosphate plays an essential role in growth of bone and teeth (Gaucheron, 2013). The mean concentration of Ca in LL milk was significantly higher than that of ML milk (Table 2). This trend is consistent with the relatively high concentration of casein in LL milk. Similarly, Keogh et al. (1982) found that the Ca content of spring-calved herd milk in late lactation (October-November) was $\sim 7-13 \mathrm{mg} / 100 \mathrm{~g}$ 
higher than the corresponding milk from early and mid lactation. However, the data of O'Brien et al. (1999b) indicated no effect of season (June-December) on the Ca content of manufacturing milk comprised mainly of spring-calved herds. A significant interaction was observed between feeding system and lactation period on Ca content, which was highest in GRO-LL milk and lowest in GRC-ML and TMR-ML milk.

Sedimentable, or micellar, Ca represents the calcium associated with the casein micelle as colloidal calcium phosphate and as calcium electrostatically attached to side chain carboxyl groups of acidic AA (Holt and Jenness, 1984). It contributes to casein interaction within the micelle and is important in the stability of milk to chymosin, heat, and ethanol (O'Connell and Fox, 2000; Horne, 2016). The mean level of sedimentable Ca, as percent of total $\mathrm{Ca}$, varied from 67 to $74 \%$ over the experimental period (Table 2). The level was notably higher than that the mean level of nondialyzable $\mathrm{Ca}$ reported by Keogh et al. (1982) for bulk milk from spring-calved cows over the year. The proportion of sedimentable Ca was significantly affected by lactation period and the interaction between lactation period and feeding system (Table 2), but not by feeding system per se. Hence, whereas the mean proportion of sedimentable Ca for LL milk was higher than that of the corresponding ML milk, the increase from mid lactation to late lactation for milk from any of the individual feeding systems was not significant. Overall, the proportion of sedimentable Ca was highest in GRO-LL milk, lowest in TMR-ML milk, and intermediate in the GRO-ML, TMR-LL, GRC-ML, and GRC-LL milk.

Phosphorus. The $\mathrm{P}$ content of milk from each of the feeding systems is shown in Table 2. The mean $\mathrm{P}$ concentration over the experimental period was relatively high, and the range relatively narrow compared with the values for mean and range reported in previous studies, for example, $65 \mathrm{mg} / 100 \mathrm{~g}$ and 54 to $78 \mathrm{mg} / 100 \mathrm{~g}$ (Keogh et al., 1982), and $78.5 \mathrm{mg} / 100 \mathrm{~g}$ and 55-112.3 mg/100 g (Sola-Larrañaga and NavarroBlasco, 2009). The high P content of the current milk samples is consistent with their relatively high casein content $(\sim 2.9-3.2 \%$, wt $/ w t)$ compared with that $(2.4-$ $2.6 \% \mathrm{wt} / \mathrm{wt})$ in milk from the foregoing studies. Hence, the mean P-to-casein ratio $(\sim 33-35 \mathrm{mg} / \mathrm{g}$ casein) for milk from each of the different feeding systems (data not shown) was comparable to that $(25.9 \mathrm{mg} / \mathrm{g}$ casein) reported by Keogh et al. (1982). Moreover, the molar ratio of Ca-to-P (1.01-1.06) of milk from the 3 feeding systems was comparable to that $(0.96)$ reported by Sola-Larrañaga and Navarro-Blasco (2009), but lower than that (1.44) found by Keogh et al. (1982). However, the use of skim milk, rather than whole milk, in the current study would have also contributed to the value of $\mathrm{P}$, and indeed all other elements, being 4 to $5 \%$ higher than that in the whole milk, owing to removal of the dilution effect by fat.

The concentration of $\mathrm{P}$ was affected by feeding system, lactation period, and their interaction. The mean $\mathrm{P}$ content of the GRO milk over the experimental period was $\sim 3$ to $5 \mathrm{mg} / 100 \mathrm{~g}$ higher than that of the corresponding GRC or TMR milk $(P<0.05)$. The mean $\mathrm{P}$ content of LL milk was significantly higher than that of ML milk. Owing to the interactive effect of feeding system and lactation period, the increase in $\mathrm{P}$ content of milk on advancing from ML to LL was significant in GRC and TMR milk but not in GRO milk.

The mean level of sedimentable $\mathrm{P}$ ranged from 62 to $68 \%$ of total $\mathrm{P}$. The mean value is high relative to that reported by White and Davies (1958) for mid lactation milk ( $\sim 52 \%)$ or Keogh et al. (1982) for spring-calved herd milk over a full lactation (51\%). The inter-study discrepancy may be associated with differences in method of determination (e.g., by dialysis, ultracentrifugation, ultrafiltration, or rennet whey) and measuring conditions (temperature and $\mathrm{pH}$ ), which affect the extent of solubilization of micellar calcium phosphate (Dalgleish and Law, 1989). The high level of sedimentable $\mathrm{P}$ is expected, as much of the $\mathrm{P}$ associates with $\mathrm{Ca}$ to form insoluble calcium phosphate, which contributes to the formation and stabilization of the casein micelle (de Kruif et al., 2012). Hence, Pearson correlation analysis of the entire data set indicated a significant positive correlation between $\mathrm{P}$ and casein $(P<0.001)$ and between $\mathrm{P}$ and $\mathrm{Ca}(P<0.001)$. The level of sedimentable $\mathrm{P}$ was affected by feeding system, lactation period, and their interaction (Table 2), with GRO milk and LL milk having relatively high levels compared with GRC milk and ML milk, respectively.

Magnesium. Magnesium partitions between the casein micelle and the serum phase of milk. In the micelle, $\mathrm{Mg}$ complexes with $\mathrm{Ca}$ and phosphate $\left(\mathrm{PO}_{4}{ }^{3-}\right)$ to form small inclusions or nanoclusters $(\sim 2 \mathrm{~nm}$ diameter) that attach to the micellar matrix of caseins via serine phosphate groups, and $\mathrm{Mg}$ in the serum phase occurs as a co-ion to citrate and inorganic phosphate (de Kruif et al., 2012). The range of Mg across all milks was of similar magnitude to that previously reported in the literature (White and Davies, 1958; Keogh et al., 1982; O'Brien et al., 1999b; Rodríguez-Rodríguez et al., 2001). The mean Mg content was unaffected by feeding system. For all feeding systems, Mg in LL milk was higher than that of the corresponding ML milk ( $P$ $<0.05$ ). Similar seasonal trends were noted by Keogh et al. (1982) and O'Brien et al. (1999b). The higher content of $\mathrm{Mg}$ in LL milk reflects its higher casein 
content; hence, Pearson correlation analysis indicated significant positive correlations between $\mathrm{Mg}$ and total casein $(P<0.001)$, and $\mathrm{Ca}$ and $\mathrm{P}(P<0.001)$.

The proportion of sedimentable $\mathrm{Mg}$ ranged from 36 to $44 \%$ of the total. Analogously, Fransson and Lönnerdal (1983) and Mekmene et al. (2009) found that most of the $\mathrm{Mg}(>62 \%)$ in cow milk was serum soluble. Sedimentable $\mathrm{Mg}$ was positively correlated with sedimentable $\mathrm{Ca}$ and $\mathrm{P}(P<0.001)$, supporting its association with $\mathrm{Ca}$ and $\mathrm{P}$ in the casein micelle. The proportion of sedimentable $\mathrm{Mg}$ was unaffected by feeding system, but significantly by lactation period and the interaction of lactation period and feeding system (Table 2). The concentration of $\mathrm{Mg}$ in LL milk was higher than that in ML milk; this trend concurs with the higher casein content in LL milk.

Sodium. The spread of Na concentration across the milks from the different feeding systems was relatively narrow compared with that reported previously [i.e., 42-85 mg/100 g (Keogh et al., 1982), 23-55 mg/100 g (Sola-Larrañaga and Navarro-Blasco, 2009), and 28-87 mg/100 g (Rodríguez-Rodríguez et al., 2001)]. Regression analysis of the current data indicated that $\mathrm{Na}$ was positively correlated with $\mathrm{Ca}, \mathrm{P}$, and $\mathrm{Mg}(P<0.01)$ and inversely with lactose content $(P<0.05)$. A similar positive correlation was found between $\mathrm{Na}$ and $\mathrm{Ca}$ or Mg by Moreno-Rojas et al. (1994) for bovine milk over a 12-mo period.

The mean $\mathrm{Na}$ content was affected significantly by lactation period and the interaction of lactation period and feeding system, but was unaffected by feeding system (Table 2). Overall the concentration of LL milk was higher than that of ML milk $(P<0.05)$. Similarly, Keogh et al. (1982) found the mean $\mathrm{Na}$ content of late-lactation milk (October 27-November 16) from a spring-calving herd was significantly higher than that of early- and mid-lactation milk (January-September). The higher concentration of Na in LL milk is consistent with its lower lactose content (Fox et al., 2015); as the lactose content decreases in late lactation, the concentrations of $\mathrm{Na}^{+}$and $\mathrm{Cl}^{-}$increase to maintain the osmotic pressure of milk in the mammary gland isotonic with that of the blood in the lactating cow (Fox, 2011).

Little information is available of the proportion of sedimentable $\mathrm{Na}$ in milk. It is generally assumed that all $\mathrm{Na}$ is soluble or nonsedimentable (Holt and Jenness, 1984). The current results showed that the mean concentration was 17.3 to $22.5 \%$ of total. The value is higher than that $(\sim 8 \%)$ reported by Sindhu and Roy (1976) for buffalo milk. Inter-study discrepancies may relate to differences in the temperature history of the sample before measurement that affect the solubility of $\mathrm{Na}$. The proportion of sedimentable $\mathrm{Na}$ was unaffected by feeding system but increased significantly with lac- tation, as indicated by the higher levels in LL milk than in ML milk (Table 2).

\section{Trace Elements in Skim Milk}

The concentrations of trace elements and the proportion of each element that sedimented on ultracentrifugation at $25^{\circ} \mathrm{C}$ are shown in Table 3 and Figure 2. For all feeding systems, the mean concentration decreased in the following order: $\mathrm{Zn}>\mathrm{Fe}>\mathrm{Cu}>\mathrm{Mo}>\mathrm{Mn}>$ Se $>$ Co. The range of concentration $(\mu \mathrm{g} / \mathrm{kg})$ for each of these elements was comparable with that reported in the literature: $\mathrm{Zn}, 2,300$ to 6,$600 ; \mathrm{Fe}, \sim 200$ to 1,500 ; $\mathrm{Cu}, 34$ to 220; Mo, 31 to $52 ; \mathrm{Mn}, 10$ to 299; Se, 6.8 to 29; and Co, 0.2 to 2.0 (Moreno-Rojas et al., 1993; O’Brien et al., 1999b; Rodríguez-Rodríguez et al., 2001; Cashman, 2011b).

Zinc. The concentration of Zn was significantly affected by feeding system, lactation period, and their interaction (Table 3; Figure 2). The mean level in TMR milk over the experimental period was significantly higher than that in GRC milk but similar to that in GRO milk; however, TMR milk had the highest $(P$ $<0.05)$ mean ratio of $\mathrm{Zn}$ to protein (i.e., $126 \mu \mathrm{g} / \mathrm{g}$ compared with $\sim 110 \mu \mathrm{g} / \mathrm{g}$ in GRO or GRC milk). The Zn concentration in LL milk was $\sim 300 \mu \mathrm{g} / \mathrm{kg}$ higher than that in ML milk. The results concur with those of Nantapo and Muchenje (2013) who found the Zn content of South African milk from cows fed on pasture, containing Lolium multiflorum L. and Trifolium repens L., was higher in winter $(4,560 \mu \mathrm{g} / \mathrm{kg})$ than in spring $(4,250 \mu \mathrm{g} / \mathrm{kg})$. In contrast, O'Brien et al. (1999b) reported that $\mathrm{Zn}$ levels in manufacturing milk varied less throughout the year, from $\sim 3,700$ to $4,300 \mu \mathrm{g} / \mathrm{kg}$.

In agreement with other studies (de la Fuente et al., 1996), Zn was predominantly ( 90\%) sedimentable. The high proportion of sedimentable $\mathrm{Zn}$ in milk has been attributed to its association with the casein micelle, most likely by interactions with phosphoseryl residues on the caseins, and calcium phosphate (Gaucheron 2013). The mean proportion of sedimentable Zn was unaffected by feeding system or lactation period.

Iron. Iron concentrations showed large variation, ranging from 215 to $1,663 \mu \mathrm{g} / \mathrm{kg}$ (Table 3 ). Other studies have also reported large seasonal variation in $\mathrm{Fe}$ content, for example, 460 to $1,490 \mu \mathrm{g} / \mathrm{kg}$ (O'Brien et al., 1999b), 190 to $1,000 \mu \mathrm{g} / \mathrm{kg}$ (Rodríguez-Rodríguez et al., 2001), and 780 to $1,560 \mu \mathrm{g} / \mathrm{kg}$ (Nantapo and Muchenje, 2013). The mean concentration was comparable to that reported by Moreno-Rojas et al. (1993; i.e., $440 \mu \mathrm{g} / \mathrm{kg})$. Feeding system or lactation period did not affect the concentration in milk $(P>0.05)$.

Copper. Copper in milk is of relevance as it can induce lipid oxidation in dairy products such as liq- 
uid milk and butter (Wedding and Deeth, 2009); Cu can also promote oxidation of proteins (Ramirez et al., 2005), which can impair the nutritional status of the protein (Meyer et al., 2012). The range of $\mathrm{Cu}$ con- centration measured in this study [i.e., $34-117 \mu \mathrm{g} / \mathrm{kg}$ (Table 3; Figure 2)], was comparable to that reported in previous studies (Moreno-Rojas et al., 1993; O’Brien et al., 1999b; Rodríguez-Rodríguez et al., 2001; Pechová

Table 3. Seasonal variation in concentration of trace elements, and the proportion of element that sediments with casein on ultracentrifugation, in skim milk from cows on different feeding systems $s^{1,2,3}$

\begin{tabular}{|c|c|c|c|c|c|c|c|c|c|}
\hline \multirow[b]{2}{*}{ Item } & \multicolumn{3}{|c|}{ Effect of feeding system } & \multicolumn{2}{|c|}{$\begin{array}{c}\text { Effect of } \\
\text { lactation period }\end{array}$} & \multicolumn{4}{|c|}{$\begin{array}{c}\text { Effect of interaction } \\
(\text { feeding system } \times \text { lactation period })\end{array}$} \\
\hline & $\begin{array}{l}\text { Feeding } \\
\text { system }\end{array}$ & Mean & Range & $\begin{array}{l}\text { Lactation } \\
\text { period }\end{array}$ & Mean & $\begin{array}{l}\text { Feeding } \\
\text { system in } \\
\text { mid lactation } \\
(\mathrm{ML})\end{array}$ & Mean & $\begin{array}{l}\text { Feeding } \\
\text { system in } \\
\text { late lactation } \\
\text { (LL) }\end{array}$ & Mean \\
\hline \multicolumn{10}{|c|}{$\begin{array}{l}\text { Total concentration } \\
\text { in milk }(\mu \mathrm{g} / \mathrm{kg})\end{array}$} \\
\hline \multirow[t]{3}{*}{ Zinc } & GRO & $4,589^{\mathrm{ab}}$ & $4,080-5,320$ & ML & $4,467^{\mathrm{b}}$ & GRO-ML & $4,480^{\mathrm{ab}}$ & GRO-LL & $4,698^{\mathrm{ab}}$ \\
\hline & GRC & $4,417^{\mathrm{b}}$ & $4,151-4,770$ & $\mathrm{LL}$ & $4,753^{\mathrm{a}}$ & GRC-ML & $4,307^{\mathrm{b}}$ & GRC-LL & $4,526^{\mathrm{ab}}$ \\
\hline & TMR & $4,822^{\mathrm{a}}$ & $4,357-5,171$ & & & TMR-ML & $4,611^{\mathrm{ab}}$ & TMR-LL & $5,034^{\mathrm{a}}$ \\
\hline \multirow[t]{3}{*}{ Iron } & GRO & $542^{\mathrm{a}}$ & $263-1,282$ & $\mathrm{ML}$ & $472^{\mathrm{a}}$ & GRO-ML & $480^{\mathrm{a}}$ & GRO-LL & $603^{\mathrm{a}}$ \\
\hline & GRC & $504^{\mathrm{a}}$ & $235-1,663$ & LL & $445^{\mathrm{a}}$ & GRC-ML & $597^{\mathrm{a}}$ & GRC-LL & $410^{\mathrm{a}}$ \\
\hline & TMR & $331^{\mathrm{a}}$ & $215-575$ & & & TMR-ML & $339^{\mathrm{a}}$ & TMR-LL & $322^{\mathrm{a}}$ \\
\hline \multirow[t]{3}{*}{ Copper } & GRO & $60.3^{\mathrm{b}}$ & $47.9-117.0$ & ML & $64.8^{\mathrm{a}}$ & GRO-ML & $70.9^{\mathrm{ab}}$ & GRO-LL & $49.8^{\mathrm{ab}}$ \\
\hline & GRC & $47.2^{\mathrm{b}}$ & $33.8-77.9$ & $\mathrm{LL}$ & $58.1^{\mathrm{a}}$ & GRC-ML & $45.7^{\mathrm{b}}$ & GRC-LL & $48.7^{\mathrm{b}}$ \\
\hline & TMR & $76.9^{\mathrm{a}}$ & $71.9-82.6$ & & & TMR-ML & $77.8^{\mathrm{a}}$ & TMR-LL & $75.9^{\mathrm{a}}$ \\
\hline \multirow[t]{3}{*}{ Molybdenum } & GRO & $45.9^{\mathrm{a}}$ & $39.5-57.6$ & ML & $42.3^{\mathrm{b}}$ & GRO-ML & $47.1^{\mathrm{ab}}$ & GRO-LL & $44.6^{\mathrm{ab}}$ \\
\hline & GRC & $43.4^{\mathrm{a}}$ & $36.4-55.4$ & LL & $48.2^{\mathrm{a}}$ & GRC-ML & $39.1^{\mathrm{b}}$ & GRC-LL & $47.8^{\mathrm{ab}}$ \\
\hline & TMR & $46.4^{\mathrm{a}}$ & $36.8-59.1$ & & & TMR-ML & $40.7^{\mathrm{ab}}$ & TMR-LL & $52.1^{\mathrm{a}}$ \\
\hline \multirow[t]{3}{*}{ Manganese } & GRO & $42.5^{\mathrm{a}}$ & $33.7-71.2$ & $\mathrm{ML}$ & $39.1^{\mathrm{a}}$ & GRO-ML & $43.2^{\mathrm{a}}$ & GRO-LL & $41.8^{\mathrm{a}}$ \\
\hline & GRC & $40.7^{\mathrm{ab}}$ & $27.1-62.1$ & & $35.8^{\mathrm{a}}$ & GRC-ML & $45.0^{\mathrm{a}}$ & GRC-LL & $36.3^{\mathrm{a}}$ \\
\hline & TMR & $29.2^{\mathrm{b}}$ & $22.6-37.3$ & & & TMR-ML & $29.0^{\mathrm{a}}$ & TMR-LL & $29.3^{\mathrm{a}}$ \\
\hline \multirow[t]{3}{*}{ Selenium } & GRO & $15.7^{\mathrm{b}}$ & $13.5-18.4$ & ML & $18.4^{\mathrm{a}}$ & GRO-ML & $16.1^{\mathrm{b}}$ & GRO-LL & $15.2^{\mathrm{b}}$ \\
\hline & GRC & $13.9^{\mathrm{b}}$ & $10.3-17.1$ & $\mathrm{LL}$ & $19.4^{\mathrm{a}}$ & GRC-ML & $13.6^{\mathrm{b}}$ & GRC-LL & $14.2^{\mathrm{b}}$ \\
\hline & TMR & $27.1^{\mathrm{a}}$ & $23.7-30.0$ & & & TMR-ML & $25.6^{\mathrm{a}}$ & TMR-LL & $28.7^{\mathrm{a}}$ \\
\hline \multirow[t]{3}{*}{ Cobalt } & GRO & $0.80^{\mathrm{a}}$ & $0.26-2.34$ & ML & $0.62^{\mathrm{b}}$ & GRO-ML & $0.54^{\mathrm{a}}$ & GRO-LL & $1.06^{\mathrm{a}}$ \\
\hline & GRC & $0.75^{\mathrm{a}}$ & $0.44-1.47$ & $\mathrm{LL}$ & $0.96^{\mathrm{a}}$ & GRC-ML & $0.66^{\mathrm{a}}$ & GRC-LL & $0.83^{\mathrm{a}}$ \\
\hline & TMR & $0.82^{\mathrm{a}}$ & $0.55-1.50$ & & & TMR-ML & $0.66^{\mathrm{a}}$ & TMR-LL & $0.98^{\mathrm{a}}$ \\
\hline \multicolumn{10}{|l|}{$\begin{array}{l}\text { Proportion } \\
\text { sedimentable } \\
\text { (\% of total) }\end{array}$} \\
\hline \multirow[t]{3}{*}{ Zinc } & GRO & $90.0^{\mathrm{a}}$ & $67.8-97.4$ & ML & $89.0^{\mathrm{a}}$ & GRO-ML & $87.0^{\mathrm{a}}$ & GRO-LL & $93.0^{\mathrm{a}}$ \\
\hline & GRC & $92.6^{\mathrm{a}}$ & $83.5-96.7$ & $\mathrm{LL}$ & $93.0^{\mathrm{a}}$ & GRC-ML & $90.0^{\mathrm{a}}$ & GRC-LL & $95.5^{\mathrm{a}}$ \\
\hline & TMR & $90.3^{\mathrm{a}}$ & $80.1-96.6$ & & & TMR-ML & $90.3^{\mathrm{a}}$ & TMR-LL & $90.4^{\mathrm{a}}$ \\
\hline \multirow[t]{3}{*}{ Copper } & GRO & $42.8^{\mathrm{a}}$ & $1.2-77.0$ & $\mathrm{ML}$ & $45.7^{\mathrm{a}}$ & GRO-ML & $36.1^{\mathrm{a}}$ & GRO-LL & $49.5^{\mathrm{a}}$ \\
\hline & GRC & $35.0^{\mathrm{a}}$ & $1.7-59.9$ & $\mathrm{LL}$ & $43.3^{\mathrm{a}}$ & GRC-ML & $42.3^{\mathrm{a}}$ & GRC-LL & $27.7^{\mathrm{a}}$ \\
\hline & TMR & $55.7^{\mathrm{a}}$ & $31.5-83.9$ & & & TMR-ML & $58.8^{\mathrm{a}}$ & TMR-LL & $52.6^{\mathrm{a}}$ \\
\hline \multirow[t]{3}{*}{ Molybdenum } & GRO & $44.4^{\mathrm{a}}$ & $23.0-66.7$ & ML & $31.0^{\mathrm{a}}$ & GRO-ML & $38.1^{\mathrm{a}}$ & GRO-LL & $50.7^{\mathrm{a}}$ \\
\hline & GRC & $34.0^{\mathrm{a}}$ & $11.8-57.9$ & $\mathrm{LL}$ & $41.9^{\mathrm{a}}$ & GRC-ML & $25.3^{\mathrm{a}}$ & GRC-LL & $42.7^{\mathrm{a}}$ \\
\hline & TMR & $30.9^{\mathrm{a}}$ & $15.0-67.0$ & & & TMR-ML & $29.6^{\mathrm{a}}$ & TMR-LL & $32.2^{\mathrm{a}}$ \\
\hline \multirow[t]{3}{*}{ Manganese } & GRO & $68.5^{\mathrm{a}}$ & $16.6-88.3$ & ML & $73.0^{\mathrm{a}}$ & GRO-ML & $65.3^{\mathrm{a}}$ & GRO-LL & $71.7^{\mathrm{a}}$ \\
\hline & GRC & $74.8^{\mathrm{a}}$ & $13.5-87.9$ & $\mathrm{LL}$ & $71.8^{\mathrm{a}}$ & GRC-ML & $79.8^{\mathrm{a}}$ & GRC-LL & $69.9^{\mathrm{a}}$ \\
\hline & TMR & $73.8^{\mathrm{a}}$ & $56.5-86.2$ & & & TMR-ML & $73.9^{\mathrm{a}}$ & TMR-LL & $73.7^{\mathrm{a}}$ \\
\hline \multirow[t]{3}{*}{ Selenium } & GRO & $72.4^{\mathrm{a}}$ & $64.2-82.1$ & ML & $71.2^{\mathrm{a}}$ & GRO-ML & $72.2^{\mathrm{a}}$ & GRO-LL & $72.6^{\mathrm{a}}$ \\
\hline & GRC & $66.4^{\mathrm{a}}$ & $55.0-80.4$ & LL & $68.2^{\mathrm{a}}$ & GRC-ML & $71.4^{\mathrm{a}}$ & GRC-ML & $61.4^{\mathrm{a}}$ \\
\hline & TMR & $70.3^{\mathrm{a}}$ & $52.0-87.9$ & & & TMR-ML & $70.0^{\mathrm{a}}$ & TMR-LL & $70.5^{\mathrm{a}}$ \\
\hline
\end{tabular}

\footnotetext{
${ }^{\mathrm{a}, \mathrm{b}}$ Values within a column relating to effect of feeding system (GRO, GRC, or TMR) and not sharing a common superscripted letter (a,b) differ significantly $(P<0.05)$. Values within a column relating to effect of lactation period (ML or LL) and not sharing a common superscripted letter (a,b) differ significantly $(P<0.05)$. Values for mid-lactation and late-lactation milk samples $(\mathrm{GRO}-\mathrm{ML}, \mathrm{GRC}-\mathrm{ML}$, TMR-ML, GRO-LL, GRCLL, or TMR-LL) relating to effect of interaction and not sharing a common superscripted letter (a,b) differ significantly $(P<0.05)$.

${ }^{1}$ Feeding system: GRO = outdoor grazing on perennial ryegrass pasture; GRC = outdoor grazing on perennial ryegrass and white clover pasture; $\mathrm{TMR}=$ indoors offered TMR.

${ }^{2}$ Lactation period: ML and LL refer to mid lactation (June 17-September 9) and late lactation (September 22-November), when cows were 119-203 and 217-281 d in lactation, respectively.

${ }^{3}$ Interaction of feeding system and lactation period: ML milk samples from GRO, GRC, or TMR feeding systems are denoted as GRO-ML, GRCML, or TMR-ML, respectively, and the corresponding LL milk samples as GRO-LL, GRC-LL, or TMR-LL, respectively.
} 
A
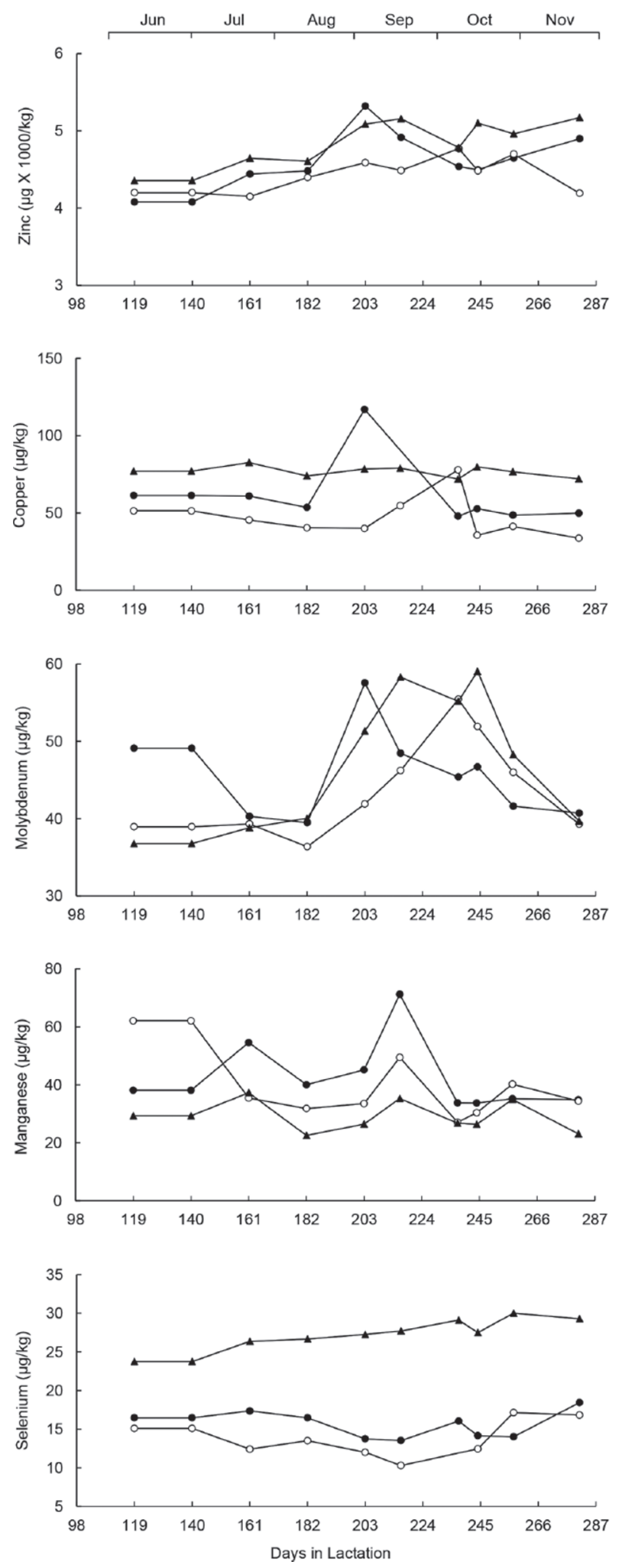

B
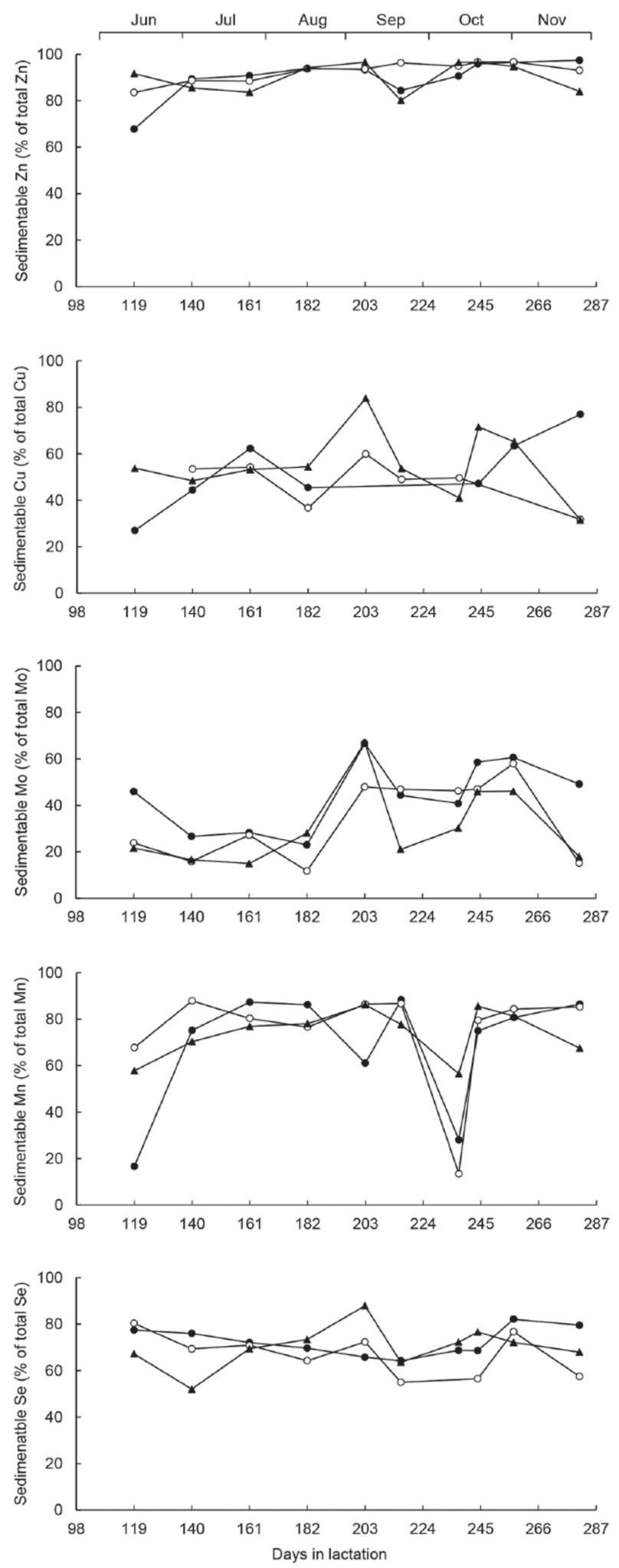

Figure 2. Seasonal variation in the concentration of trace elements in skim milk from spring-calved herds fed using different feeding systems: total concentration (A) and the proportion of each element that sedimented with the casein on ultracentrifugation at $100,000 \times g$ for $1 \mathrm{~h}$ at $25^{\circ} \mathrm{C}$ (B). The different feeding systems were outdoor grazing perennial ryegrass $(\bullet)$, outdoor grazing perennial ryegrass and white clover pasture $(\bigcirc)$, or indoors offered TMR $(\boldsymbol{\Lambda})$. Milk from each of the feeding systems was analyzed over the period June 17 to November $26,2015$. 
et al., 2008; Sola-Larrañaga and Navarro-Blasco, 2009; Nantapo and Muchenje, 2013).

The concentration of $\mathrm{Cu}$ was affected by feeding system and the interaction of feeding system and lactation period, but not by lactation period. The TMR milk had the highest $(P<0.05)$ mean concentration of $\mathrm{Cu}$ over the experimental period, and $\mathrm{Cu}$-to-protein ratio (i.e., $2.01 \mu \mathrm{g} / \mathrm{g}$ compared with $1.46 \mu \mathrm{g} / \mathrm{g}$ in GRO milk or $1.20 \mu \mathrm{g} / \mathrm{g}$ in GRC milk). Analogously, other studies have also found that the $\mathrm{Cu}$ content of milk increases when cows were brought indoors from pasture in late autumn and switched to a diet that relies more on concentrates (Ford et al., 1986; O'Brien et al., 1999b). The relatively low $\mathrm{Cu}$ content of milk from pasture-fed cows has been attributed to the poor bioavailability of $\mathrm{Cu}$ from fresh grass pasture due to the presence of Mo and inorganic sulfur in the grass, which suppress $\mathrm{Cu}$ absorption (Ford et al., 1986).

The mean proportion of sedimentable $\mathrm{Cu}$ varied from 35 to $56 \%$ of total, and was not affected by feeding system or lactation period. The result concurs with the findings of previous studies, which found that $\mathrm{Cu}$ partitions with fat globules, sedimentable casein, and serum (specifically with whey proteins and low molecular weight protein fractions with molecular mass $<10 \mathrm{kDa}$ ) at levels of $\sim 2,44$, and $55 \%$ of the total, respectively (Fransson and Lönnerdal, 1983; Al-Awadi and Srikumar, 2001; Gaucheron, 2013).

Molybdenum. Milk may contribute as much as $\sim 36 \%$ of the recommended daily allowance for Mo. It is an essential component of several enzymes, including xanthine oxidase, which is associated mainly with the fat globule membrane (Cashman, 2011b). The range and mean of Mo concentration for the GRO, GRC, and TMR milk samples (Table 2) were comparable to those reported by O'Brien et al. (1999b) for manufacturing milk (range, 27-51 $\mu \mathrm{g} / \mathrm{kg}$; mean, $39.5 \mu \mathrm{g} / \mathrm{kg}$ ). Molybdenum was affected by lactation period and the interaction of lactation period and feeding system $(P<0.05)$, but not by feeding system. The mean concentration of Mo in LL milk was higher than that in ML milk; for all feeding systems, the concentration increased to a peak value at 203 to 245 DIL and thereafter decreased (Figure 2). A similar seasonal trend was observed by O'Brien et al. (1999b) for bulk manufacturing and retail milk.

The mean proportion of sedimentable Mo ranged from 31 to $44 \%$ of total and was not affected by feeding system or lactation period. The authors are unaware of published data on the partitioning of Mo between sedimentable and serum phases in milk.

Manganese. The range of Mn concentration across all milk samples was comparable to that reported previ- ously (Moreno-Rojas et al., 1993; O'Brien et al., 1999b; Pechová et al., 2008; Sola-Larrañaga and NavarroBlasco, 2009; Nantapo and Muchenje, 2013). The mean concentration in the GRO milk was markedly higher $(P<0.05)$ than that in the TMR milk, but did not differ from that in the GRC milk (Table 3). Analogously, O'Brien et al. (1999b) reported that the Mn content of manufacturing milk was slightly higher when cows grazed outdoors on pasture (June-October) than when they were fed indoors on silage with concentrate supplementation. Manganese content was unaffected by lactation period or the interaction of feeding system and lactation period.

The mean proportion of sedimentable $\mathrm{Mn}, \sim 69$ to $75 \%$ of the total, was similar to that reported by AlAwadi and Srikumar (2001) and was not influenced by feeding system or lactation period.

Selenium. The range of Se concentration in all milks over the experimental period was comparable in magnitude to that reported by Rodríguez-Rodríguez et al. (2001) and Pechová et al. (2008). The concentration of Se was affected by feeding system but not by lactation period. The mean concentration of Se in TMR milk was significantly higher than that of GRO or GRC milk (Table 3; Figure 2); the Se-to-protein ratio of TMR milk $(0.67 \mu \mathrm{g} / \mathrm{g})$ was also higher $(P<0.05)$ than that of GRO or GRC milk $(0.38 \mu \mathrm{g} / \mathrm{g})$ or GRC milk $(0.25$ $\mu \mathrm{g} / \mathrm{g})$. Considering that the Se content in milk increases with the level in the diet (Givens et al., 2004; Heard et al., 2007), the higher Se in TMR milk may reflect a higher Se content in TMR compared with pasture, owing to its inclusion of molasses, a relatively rich source of Se (Givens et al., 2004; Heard et al., 2007).

The level of sedimentable Se was unaffected by feeding system or lactation period. The high proportion of sedimentable Se, which has also been reported in previous studies ( $\sim 55-75 \%$, Knowles et al., 1999), reflects its binding to milk protein, especially casein (Van Dael et al., 1991). In contrast, Al-Awadi and Srikumar (2001) found that $\sim 80 \%$ of Se in skim milk was found in the serum where it was associated with whey proteins and low molecular weight protein fractions.

Cobalt. Cobalt concentration ranged from 0.26 to $1.5 \mu \mathrm{g} / \mathrm{kg}$ across all samples collected over the experimental period. The mean concentration was unaffected by feeding system but was affected by lactation period, with the level in LL milk being higher than that of ML milk (Table 3). The range and mean of Co concentration are comparable to those given by Cashman (2011b; i.e., range, $0.4-1.1 \mu \mathrm{g} / \mathrm{kg}$, with a mean of $0.5 \mu \mathrm{g} / \mathrm{kg}$ ). The data of O'Brien et al. (1999b) showed a wider range $(0.2-2.7 \mu \mathrm{g} / \mathrm{kg})$ and higher mean concentration $(1.0-1.3 \mu \mathrm{g} / \mathrm{kg})$. 


\section{Correlation of Variables}

The data for all milk samples collected over the experimental period were analyzed by linear regression to establish potential inter-relationships. The analysis indicated significant positive correlation between the concentration of protein or casein and the total, and sedimentable, concentrations of $\mathrm{Ca}, \mathrm{P}, \mathrm{Mg}, \mathrm{Na}$, and Zn $(P<0.01)$, and Mo $(P<0.05)$. Significant interrelationships were also observed between the concentrations of the macroelements, $\mathrm{Ca}, \mathrm{P}, \mathrm{Mg}$, and $\mathrm{Na}(P<$ 0.01). Positive correlations between macroelements and trace elements included $\mathrm{Ca}$ or $\mathrm{Mg}$ with $\mathrm{Zn}, \mathrm{Fe}, \mathrm{Mo}$, and Co; P with $\mathrm{Zn}$ and $\mathrm{Mo}$; and $\mathrm{Na}$ with $\mathrm{Mo}(P<0.05)$. The strong correlations between $\mathrm{Ca}, \mathrm{P}$, and $\mathrm{Mg}$ are consistent with the pivotal role played by these elements in casein micelle formation and stability (Holt and Jenness, 1984; de Kruif et al., 2012). The concentrations of $\mathrm{Cu}$ and Se, both of which were high in TMR milk, were positively correlated $(P<0.001)$.

\section{CONCLUSIONS}

The study investigated the effect of 3 different feeding systems (perennial ryegrass, GRO; perennial ryegrass and white clover, GRC; or total mixed ration, TMR) on composition and yield of spring-calved herd milk. Feeding system influenced the concentration and yield of TS, fat, lactose, protein, casein, macroelements, and trace-elements. The changes in milk composition with feeding system have potential implications for product manufacture and quality. The relatively high protein and casein content of GRO milk, despite the lower milk yield, would be advantageous in terms of reducing the plant capacity required for the manufacture of dairy products and ingredients. Differences in the concentration of milk protein and the ratio of individual elements-to-protein are of particular relevance when formulating products with target levels of protein and minerals from dairy ingredients, for example, beverages such as IMF, and medical or therapeutic applications. Nevertheless, the consistency of any feeding system is likely to vary owing to differences in grazing strategies, type and level of fertilization, soil type and weather in the case of pasture, and to the proportions and consistency of ingredients used in TMR formulation.

\section{ACKNOWLEDGMENTS}

This study was funded by the Department of Agriculture, Food and the Marine (Dublin, Ireland) Stimulus fund (11/sf/309), and additionally supported by funding from the Dairy Levy Trust Co-Operative Society Limited (Dublin, Ireland). The authors acknowledge
Paula Reid, Ashtown Food Research Centre Teagasc, for assistance with the statistical analysis of the data.

\section{REFERENCES}

Al-Awadi, F. M., and T. Srikumar. 2001. Trace elements and their distribution in protein fractions of camel milk in comparison to other commonly consumed milks. J. Dairy Res. 68:463-469.

Auldist, M. J., K. A. Johnston, N. J. White, W. P. Fitzsimons, and M. J. Boland. 2004. A comparison of the composition, coagulation characteristics and cheesemaking capacity of milk from Friesian and Jersey dairy cows. J. Dairy Res. 71:51-57.

Cashman, K. D. 2011a. Milk salts: Macroelements, nutritional significance. Pages 925-932 in Encyclopedia of Dairy Sciences. Vol. 3. J. W. Fuquay, P. F. Fox, and P. L. H. McSweeney, ed. Academic Press, London, UK.

Cashman, K. D. 2011b. Milk salts: Trace elements, nutritional significance. Pages 933-940 in Encyclopedia of Dairy Sciences. Vol. 3. J. W. Fuquay, P. F. Fox, and P. L. H. McSweeney, ed. Academic Press, London, UK.

Dalgleish, D. G., and A. J. Law. 1989. pH-induced dissociation of bovine casein micelles. II. Mineral solubilization and its relation to casein release. J. Dairy Res. 56:727-735.

de Kruif, C. G., T. Huppertz, V. S. Urban, and A. V. Petukhov. 2012. Casein micelles and their internal structure. Adv. Colloid Interface Sci. 171-172:36-52.

de la Fuente, M. A., J. Fontecha, and M. Juárez. 1996. Partition of main and trace minerals in milk: Effect of ultracentrifugation, rennet coagulation, and dialysis on soluble phase separation. J. Agric. Food Chem. 44:1988-1992.

European Commission. 2006. Commission Directive 2006/141/EC of 22 December 2006 on infant formulae and follow-on formulae and amending Directive 1999/21/EC. Off. J. Eur. Union L401/1-33.

Ford, J. E., M. J. Schröder, M. A. Bland, K. S. Blease, and K. J. Scott. 1986. Keeping quality of milk in relation to the copper content and temperature of pasteurization. J. Dairy Res. 53:391-406.

Fox, P. F. 2011. Lactose and oligosaccharides: Lactose: Chemistry, properties. Pages 173-181 in Encyclopedia of Dairy Sciences. Vol 3. J. W. Fuquay, P. F. Fox, and P. L. H. McSweeney, ed. Academic Press, London, UK.

Fox, P. F., P. L. H. McSweeney, T. Uniacke-Lowe, and J. A. O'Mahony. 2015. Salts of milk. Pages 241-270 in Dairy Chemistry and Biochemistry. Springer International Publishing, Cham, Switzerland.

Fransson, G.-B., and B. Lönnerdal. 1983. Distribution of trace elements and minerals in human and cow's milk. Pediatr. Res. 17:912-915.

Gaucheron, F. 2013. Milk minerals, trace elements, and macroelements. Pages 172-199 in Milk and Dairy Products in Human Nutrition: Production, Composition and Health. Y. W. Park and G. F. W. Haenlein, ed. Wiley-Blackwell, UK.

Givens, D. I., R. Allison, B. Cottrill, and J. S. Blake. 2004. Enhancing the selenium content of bovine milk through alteration of the form and concentration of selenium in the diet of the dairy cow. J. Sci. Food Agric. 84:811-817.

Guinee, T. P., B. T. O'Kennedy, and P. M. Kelly. 2006. Effect of milk protein standardization using different methods on the composition and yields of cheddar cheese. J. Dairy Sci. 89:468-482.

Heard, J. W., C. R. Stockdale, G. P. Walker, C. M. Leddin, F. R. Dunshea, G. H. McIntosh, P. M. Shields, A. McKenna, G. P. Young, and P. T. Doyle. 2007. Increasing selenium concentration in milk: Effects of amount of selenium from yeast and cereal grain supplements. J. Dairy Sci. 90:4117-4127.

Holt, C., and R. Jenness. 1984. Interrelationships of constituents and partition of salts in milk samples from eight species. Comp. Biochem. Physiol. A Comp. Physiol. 77:275-282.

Horne, D. S. 2016. Ethanol Stability and Milk Composition. Pages 225-246 in Advanced Dairy Chemistry. Vol 1B: Proteins: Applied Aspects. P. L. H. McSweeney and J. A. O'Mahony, 4th ed. Springer, New York, NY.

IDF. 2001. Milk-Determination of nitrogen content-Part 1: Kjeldahl method. International Dairy Federation, Brussels, Belgium. 
ISO. 2004. Milk-Determination of casein-nitrogen content. Part 1 in Indirect Method. Vol. ISO-17997-1. International Standardization Organization, Geneva, Switzerland.

Keogh, M., P. Kelly, A. O'Keeffe, and J. Phelan. 1982. Studies of milk composition and its relationship to some processing criteria: II. Seasonal variation in the mineral levels of milk. Int. J. Food Sci. Technol. 6:13-27.

Knowles, S., N. Grace, K. Wurms, and J. Lee. 1999. Significance of amount and form of dietary selenium on blood, milk, and casein selenium concentrations in grazing cows. J. Dairy Sci. 82:429-437.

Kolver, E., and L. Muller. 1998. Performance and nutrient intake of high producing Holstein cows consuming pasture or a total mixed ration. J. Dairy Sci. 81:1403-1411.

Ledgard, S., R. Schils, J. Eriksen, and J. Luo. 2009. Environmental impacts of grazed clover/grass pastures. Ir. J. Agric. Food Res. 48:209-226.

McAuliffe, S., T. Gilliland, M. Egan, and D. Hennessy. 2016. Comparison of pasture based feeding systems and a total mixed ration feeding system on dairy cow milk production. Pages 376-378 in Proc. of the 26th General Meeting of the European Grassland Federation, Trondheim, Norway, 4-8 September 2016.

McCarthy, N. A., K. M. Murphy, and M. A. Fenelon. 2016. Infant Follow-On Foods in Reference Module in Food Science. Elsevier Inc. Accessed Aug. 9, 2017. https://doi.org/10.1016/B978-0-08 -100596-5.21033-0.

McSweeney, S., J. O'Regan, and D. O'Callaghan. 2013. Nutritional formulae for infants and young children. Pages 458-497 in Milk and Dairy Products in Human Nutrition: Production, Composition and Health. Y. W. Park and G. F. W. Haenlein, ed. WileyBlackwell, UK.

Mehra, R., B. O’Brien, J. Connolly, and D. Harrington. 1999. Seasonal variation in the composition of Irish manufacturing and retail milks: 2. Nitrogen fractions. Irish J. Agric. Food Res. 38:65-74.

Mekmene, O., Y. Le Graët, and F. Gaucheron. 2009. A model for predicting salt equilibria in milk and mineral-enriched milks. Food Chem. 116:233-239.

Meyer, B., F. Baum, G. Vollmer, and M. Pischetsrieder. 2012. Distribution of protein oxidation products in the proteome of thermally processed milk. J. Agric. Food Chem. 60:7306-7311.

Moreno-Rojas, R., M. Amaro-Lopez, and G. Zurera-Cosano. 1993. Micronutrients in natural cow, ewe and goat milk. Int. J. Food Sci. Nutr. 44:37-46.

Moreno-Rojas, R., G. Zurera-Cosano, and M. A. Amaro-Lopez. 1994. Concentration and seasonal variation of calcium, magnesium, sodium and potassium in raw cow, ewe and goat milk. Int. J. Food Sci. Nutr. 45:99-105.

Nantapo, C., and V. Muchenje. 2013. Winter and spring variation in daily milk yield and mineral composition of Jersey, Friesian cows and their crosses under a pasture-based dairy system. S. Afr. J. Anim. Sci. 43(Suppl. 1):s17-s21.

O'Brien, B., R. Mehra, J. Connolly, and D. Harrington. 1999a. Seasonal variation in the composition of Irish manufacturing and retail milks: 1. Chemical composition and renneting properties. Ir. J. Agric. Food Res. 38:53-64.

O'Brien, B., R. Mehra, J. Connolly, and D. Harrington. 1999b. Seasonal variation in the composition of Irish manufacturing and retail milks: 4. Minerals and trace elements. Ir. J. Agric. Food Res. 38:87-99.

O'Callaghan, T. F., H. Faulkner, S. McAuliffe, M. G. O'Sullivan, D. Hennessy, P. Dillon, K. N. Kilcawley, C. Stanton, and R. P. Ross. 2016a. Quality characteristics, chemical composition, and sensory properties of butter from cows on pasture versus indoor feeding systems. J. Dairy Sci. 99:9441-9460.

O'Callaghan, T. F., D. Hennessy, S. McAuliffe, K. N. Kilcawley, M. O'Donovan, P. Dillon, R. P. Ross, and C. Stanton. 2016b. Effect of pasture versus indoor feeding systems on raw milk composition and quality over an entire lactation. J. Dairy Sci. 99:9424-9440.
O'Callaghan, T. F., D. Hennessy, S. McAuliffe, J. J. Sheehan, K. N. Kilcawley, P. Dillon, R. P. Ross, and C. Stanton. 2017. A pasturebased diet improves nutritional composition and quality measures of milk, butter and Cheddar cheese. Pages 208-211 in Irish Dairying Resilient Technologies, Moorepark Animal \& Grassland Research and Innovation Centre, Teagasc, Moorepark, Fermoy, Co. Cork, Ireland.

O'Connell, J., and P. Fox. 2000. The two-stage coagulation of milk proteins in the minimum of the heat coagulation time-pH profile of milk: Effect of casein micelle size. J. Dairy Sci. 83:378-386.

O'Mara, F. P. 2008. Country pasture/forage resource profile/Ireland. Accessed Jun. 14, 2017. http://www.fao.org/ag/AGP/AGPC/ doc/pasture/forage.htm.

O'Neill, B., M. Deighton, B. O'Loughlin, F. Mulligan, T. Boland, M. O'Donovan, and E. Lewis. 2011. Effects of a perennial ryegrass diet or total mixed ration diet offered to spring-calving HolsteinFriesian dairy cows on methane emissions, dry matter intake, and milk production. J. Dairy Sci. 94:1941-1951.

Pechová, A., L. Pavlata, R. Dvořák, and E. Lokajová. 2008. Contents of $\mathrm{Zn}, \mathrm{Cu}, \mathrm{Mn}$ and Se in milk in relation to their concentrations in blood, milk yield and stage of lactation in dairy cattle. Acta Vet. Brno 77:523-531.

R Core Team. 2014. R: A language and environment for statistical computing. R Foundation for Statistical Computing, Vienna, Austria. http://www.R-project.org/.

Ramirez, D. C., S. E. G. Mejiba, and R. P. Mason. 2005. Coppercatalyzed protein oxidation and its modulation by carbon dioxide enhancement of protein radicals in cells. J. Biol. Chem. 280:2740227411.

Reid, M., M. O'Donovan, C. T. Elliott, J. S. Bailey, C. J. Watson, S. T. J. Lalor, B. Corrigan, M. A. Fenelon, and E. Lewis. 2015. The effect of dietary crude protein and phosphorus on grass-fed dairy cow production, nutrient status, and milk heat stability. J. Dairy Sci. 98:517-531.

Rodríguez Rodríguez, E. M., M. Sanz Alaejos, and C. Diaz Romero. 2001. Mineral concentrations in cow's milk from the Canary Island. J. Food Compos. Anal. 14:419-430.

Sandra, S., M. Ho, M. Alexander, and M. Corredig. 2012. Effect of soluble calcium on the renneting properties of casein micelles as measured by rheology and diffusing wave spectroscopy. J. Dairy Sci. 95:75-82.

Sievanen, K., T. Huppertz, A. L. Kelly, and P. F. Fox. 2008. Influence of added calcium chloride on the heat stability of unconcentrated and concentrated bovine milk. Int. J. Dairy Technol. 61:151-155.

Sindhu, J., and N. Roy. 1976. Partitioning of buffalo milk minerals, 2: Study through ultracentrifugation. Milchwissenschaft 31:479-483.

Sola-Larrañaga, C., and I. Navarro-Blasco. 2009. Chemometric analysis of minerals and trace elements in raw cow milk from the community of Navarra, Spain. Food Chem. 112:189-196.

Tsioulpas, A., M. J. Lewis, and A. S. Grandison. 2007. Effect of minerals on casein micelle stability of cows' milk. J. Dairy Res. 74:167-173.

Van Dael, P., G. Vlaemynck, R. Van Renterghem, and H. Deelstra. 1991. Selenium content of cow's milk and its distribution in protein fractions. Zeitschrift Lebensmittel Untersuch. und-Forsch. 192:422-426.

Verkerk, G. 2003. Pasture-based dairying: Challenges and rewards for New Zealand producers. Theriogenology 59:553-561.

Wedding, B. B. C., and H. C. Deeth. 2009. Trouble shooting. Pages 286-315 in Dairy Fats and Related Products. A. Y. Tamine, ed. Blackwell Publishing, Oxford, UK.

White, J., and D. Davies. 1958. The relation between the chemical composition of milk and the stability of the caseinate complex: I. General introduction, description of samples, methods and chemical composition of samples. J. Dairy Res. 25:236-255. 